\title{
CALVING PERFORMANCE IN DANISH BREEDS \\ OF DUAL PURPOSE CATTIE
}

M. Hansen. - Institute of Animal Science, 23, Rolighedsvey, 1958, Copenhagen (Denmark).

Calving performance is discussed as one of the main factors of stillbirths in cattle.

Data from 1784 first calvings in two dual purpose Danish breeds of cattle (Red Danish and Black Pied Danish) were analysed. The data originate from the progeny testing stations, and calving performance was scored on a scale :

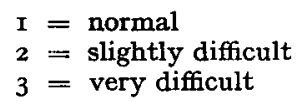

Heritability for the scored calving performance was calculated in two different ways, the results ranging from 0.13 to 0.32 for Red Danish and from o. Io to 0.18 for Black Pied Danish.

The phenotypic correlation between calving difficulty score and weight of calf was found to be between 0.18 and 0.26 for both breeds.

The size of the genetic correlations indicate that in the Red Danish breed the bigger heifers have the easiest calvings. For the Black Pied breed the smallest heifers have the easiest calvings. For both breeds the greater width of hips and thurls are followed by more difficult calvings.

\section{SELECTION FOR MILK PROTEIN}

\author{
P. H. Petersen, - Institute of Animal Science, 23, Rolighedsvey, 1958, Copenhagen (Denmark).
}

As seen from the intervention prices, EEC attaches more and more importance to the milk protein and accordingly less importance to the butterfat. On this background is given an evaluation of the previous investigations regarding the genetic improvement of the cow's protein yield. It is concluded that if introducing protein registration this must be as a supplement to the present fat test, and that the most profitable alternative must be a limited and not too cost demanding registration.

An investigation of the economic consequence in connection with the following 3 registration systems is carried out : registration among the potential bull dans, among the bull sire candidates, and among all first lactation cows. The last alternative turns out to be the most profitable Moreover investigations indicate that one protein test per every second or third of the present 13 fat tests per year is sufficient. Further the results indicate that a saving of $4-6 \mathrm{D}$. Kr. per cow In costs when taking samples and laboratory analyses will justify a reduction in the number of both fat and protein tests.

\section{GENETIC RELATIONSHIP BETWEEN THYROID ACTIVTTY AND MILK YIELD IN CATTLE}

\section{Ø. Joakimsen. - Agricultural University of Norway, Aas-NLH, Norway.}

The economically important characters in animal production represent the final links in complicated chains of biochemical processes. In the regulation of these enzyme-catalyzed processes the hormones play an important role. Accordingly, it is a fairly good reason to formulate the hypothesis that endocrinological activity may reflect the genotype of an individual for economically important characters. If there really exist genetically determined associations between such physiological parameters and production characters, they could be of great value as selection criteria.

The significance of the thyroid hormones in the regulation of milk secretion is documented in numerous experiments. However, the existence of a genetic correlation between the thyroid function and milk yield is still questionable. In order to shed some light on this field we estimated 
the daily thyroxine degradation on 98 mature AI bulls in 1968 . Based on this material and the corresponding progeny tests for milk yield we estimated a genetic correlation of +0.40 between the two traits concerned. The results of this investigation inspired us to carry out a similar investigation on young bulls before they were inserted into AI. About eighty of these bull will be progenytested this year. Preliminary calculations have shown a positive correlation between the thyroxine degradation of the bulls and maximum daily milk yield of their daughters.

The thyroxine degradation has up to now been based upon the plasma level of protein bound iodine. The informative value of more specific information about plasma level of thyroxine and triiodothyronine will now be tested.

Reçu pour publication en mars 1975. 